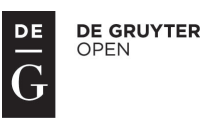

\title{
The KaZaKhstan-European Union PARTNERShip: MODERNIZATION OF THE REPUBLIC'S FINANCIAL SYSTEM
}

\author{
Jarosław Marczak ${ }^{1}$, Natalya Uvarova ${ }^{2}$
}

\begin{abstract}
This study examines the issue of the modernization of the Kazakh financial system considering the new, Enhanced Partnership and Cooperation Agreement with the European Union (EU) (January 19, 2015) and the Kazakh State program "Path to Europe, 2009-2011". It describes new opportunities for the establishment of a long-term partnership and cooperation between Kazakhstan and the EU for the restructuring of Kazakhstan's financial system and its convergence with international standards and European regulations. Specifically, this study covers the financial policy and the objectives of the Republic's financial sector management; legislation regulating the financing activity of business entities, particularly its transparency and accessibility to foreign investors; contradictions between the legal framework of the state on financial relations and international standards, European directives, conventions, and recommendations; and the security of financing activities of European companies. This study employs general scientific methods (theoretical analysis and generalization, comparative legal, logical, etc.) and the functional approach.
\end{abstract}

\section{Keywords}

Finance, Financial System, International Standards and EU Directives, Financial Policy, Management, Financial Crisis, Regulation

\section{Introduction}

Solving the current problems of Kazakhstan's economic and financial sector development invariably requires foreign experience, particularly from the countries of the European Union. For that purpose, the Republic has adopted a State program called "Path to Europe"3. Adopting this program was vital due to the importance of solving the problems

\footnotetext{
${ }^{1}$ Faculty of Economics and Sociology, University of Lodz, 3/5 POW Street, 90-255 Lodz, Poland. E-mail: marczak.jaroslaw@gmail.com.

${ }^{2}$ Department of Accounting and Audit, Caspian University, Seifullin avenue 521, Almaty, Republic of Kazakhstan: E-mail: uvarova.natalya@yahoo.com.

${ }^{3}$ Decree of the President of the Republic of Kazakhstan, dated January 29, 2008. No. 653.
} 
of the country's internal development, developing national priorities in the European direction, strengthening historical relationships, adopting European integration experience and institution and legal reforms, enhancing cooperation in such fields as technology, energy, transport, trade, and humanities.

The European Union, in turn, devotes considerable attention to cooperation with Kazakhstan and other countries in Central Asia ${ }^{4}$. B. Ferrero-Waldner, former EU Commissioner for External Relations and European Neighbourhood Policy, claims that "Kazakhstan is a pivotal partner in Central Asia for the EU. We support democratic and economic reforms, enhance cooperation in the power industry relying on our well-developed trade relations, and look for new ways to contribute to regional stability in Central Asia together"s.

The European Union is one of the Republic's major business partners. Kazakhstan and the European Union have now entered a new, expanded Agreement on Partnership and Cooperation (dated January 19, 2015). In light of this Agreement and the State Program "Path to Europe", the problem of modernization of the Republic's financial system becomes crucial. The solution to this problem meets the requirements of social development, improvement of public finance management practices, and socioeconomic reforms in the Republic. Based on a solid legal platform, it is aimed at the convergence of the Kazakh financial system with international standards and EU regulations, and provides the necessary degree of competitiveness of the national financial system amid open "financial borders" following Kazakhstan's entry into the World Trade Organization ${ }^{6,7,8}$.

This subject has not yet been thoroughly analyzed in the Republic's financial scien$\mathrm{ce}^{9,10,11,12}$. It is therefore highly relevant, correlates with the "Kazakhstan-2050" Strategy ${ }^{13}$ and the concept of the development of the financial sector of the Republic of Kazakhstan until $2030^{14}$.

\section{Prerequisites for a long-term partnership between Kazakhstan and the $\mathbf{E U}$}

Kazakhstan has favorable conditions for the establishment of a long-term partnership with the EU and vast reserves of natural resources, particularly energy resources. It has vast oil and gas deposits, coal, uranium, gold, and other valuable metals and minerals. The potential for utilizing solar and wind energy is huge. It specifically focuses on economic sectors such as natural resources development, infrastructure, communication and information, and

\footnotetext{
${ }^{4}$ Georg-Eckert-Institut - Leibniz-Institut für internationale Schulbuchforschung (2016).

${ }^{5}$ European Commission (2006).

${ }^{6}$ The Constitution of the Republic of Kazakhstan (1995).

${ }^{7}$ Law of the Republic of Kazakhstan, dated May 30, 2005. No. 54.

${ }^{8}$ Regulatory Statute of the Constitutional Council of the Republic of Kazakhstan, dated November 5, 2009. No. 6.

${ }^{9}$ Abishev, Sidorovich (2009).

${ }^{10}$ Intykbayeva (2007).

${ }^{11}$ Melnikov (2013).

${ }^{12}$ Utibayev, Zhunusova, Satkaliyeva (2006).

${ }^{13}$ Nazarbayev (2012).

${ }^{14}$ Order of the Government of the Republic of Kazakhstan, dated August 27, 2014. No. 954.
} 
industrial technology. These issues are addressed in the Strategic Plan for the Development of the Republic of Kazakhstan until $2020^{15}$. All these are the components of the public finance management system that correspond to the economic infrastructure capable of providing dynamic development of the economy and withstanding external challenges.

Political stability and social unity are two major factors in the development of Kazakhstan. Unlike developing and post-Soviet countries, Kazakhstan avoided civil war and managed to maintain stability. The patience and tolerance shown by the people of Kazakhstan during the transition period is the cornerstone of this success. The "Kazakhstan 2050" strategy endorsed positive trends in society, enabling the country to undertake large-scale socioeconomic reforms and develop a competitive national financial system.

Another factor impacting the public financial management system and its protection from external influences is the fact that years of independence have created favorable external conditions for the development of Kazakhstan. Kazakhstan has become an equal participant in the international community. Its financial system is integrated into the global financial system, as evidenced by the Republic's membership of numerous international financial organizations ${ }^{16}$. This means that international standards and regulations, as well as the decisions and recommendations of international financial organizations directly impact the development of the Republic's financial sector.

The "Kazakhstan 2050" strategy defines long-term priorities in foreign policy, such as creating and maintaining a favorable external environment for the country's development and retaining its competitiveness in the modern world; protecting the sovereignty and territorial integrity of the Republic; protecting the rights and interests of individuals and legal bodies abroad; creating a positive image and perception of the Republic in the world as a democratic constitutional state with a modern market economy, maintaining a stable political system and an open, tolerant society; protecting the country's economic interests internationally; and actively participating in international organizations and forums. This ensures a consistent and predictable foreign policy aimed at promoting national interests as well as enhancing regional and global security.

Kazakhstan's role has been steadily expanding globally. It is the world's ninth biggest country, occupying a territory equal to that of Western Europe. Its confirmed oil reserves rank ninth in the world, while its hydrocarbon production constitutes approximately a quarter of GDP and more than two thirds of the country's exports. These make for solid prerequisites for economic development and for creating conditions for a high standard of living, as well as for organizing production and strengthening foreign economic relations. An important external factor in the development of the Republic's financial system is using additional opportunities such as foreign aid to implement the country's socioeconomic reforms. Kazakhstan's engagement with the global community offers a unique opportunity to access new technologies, particularly in information and telecommunication domains. This is particularly important for Kazakhstan, with its vast, yet underpopulated territory. The rejuvenation of the economy requires a considerable inflow of investments as well as increased national savings and accumulation of capital.

\footnotetext{
${ }^{15}$ Decree of the President of the Republic of Kazakhstan, dated February 1, 2010. No. 922.

${ }^{16}$ Law of the Republic of Kazakhstan, dated December 6, 2001 No. 264-II.
} 
The Republic enjoys a strategic geographical location, lying at the crossroads of the Eurasian region. Kazakhstan borders Russia, China, and several Central Asian countries. This is a key factor for its position in the global economic system. As is well known, the legendary Silk Road was the channel for the extensive trade between Asian and European countries. The regional potential of Kazakhstan for energy and trade is being increasingly recognized, and this strategically important trade channel is being restored in close cooperation with other countries in the region. This is expected to increase financial flows, human migration, and trade between Europe and Asia. Strategically, Kazakhstan connects the large and rapidly growing markets of China and South Asia with Western Europe through motor and rail transport and ports in the closed Caspian Sea. The increase in financial flows, human migration, and trade between Europe and Asia will create new types of international relations and interactions with neighboring states.

Similar to other neighboring states, it is difficult for Kazakhstan to unlock the transit potential of the region by itself. This is possible only through concerted efforts on mutually agreed conditions. Thus, President Nazarbayev mooted the idea of "Eurasianism" and is now developing it, after recognizing it as the strategic future. This idea is currently being implemented through multilateral economic cooperation with other states in the region based on common benefits and national interests.

Simultaneously, there are many obstacles to cooperation between Kazakhstan and the EU because of the immaturity of the so-called "financial component". Enhancing cooperation in currency relations has become increasingly important, given its role in fostering the economic development of Kazakhstan and reducing its sensitivity to external financial shocks. The convergence of the Kazakh financial system with that of Europe is a priority for their cooperation.

The implementation of the "Path to Europe, 2009-2011" program depends on Kazakhstan reaching a level of strategic partnership with leading European countries in the political, economic, and humanitarian fields. Favorable conditions are being created for annual growth in the volume of trade with European countries; technical regulations and harmonized standards are being made to conform to EU requirements; laws are being refined in accordance with European norms; and Kazakh interests are being promoted in Europe. In turn, the new Kazakhstan-EU Enhanced Partnership and Cooperation Agreement ${ }^{17}$ provides a legal framework for strengthening relations based on common interests.

\section{Kazakhstan-EU partnership: Financial policy and goals of financial sector management}

The new Kazakhstan-EU Enhanced Partnership and Cooperation Agreement (2015) and the state program, "Path to Europe, 2009-2011" make it necessary to consider the financial policy and goals of the Republic's financial sector management. The financial policy of the State is determined by the Concept of Development of the Financial Sector of the Republic of Kazakhstan until $2030^{18}$. It reflects the vision for the development of the financial sector

\footnotetext{
${ }^{17}$ Decree of the President of the Republic of Kazakhstan, dated January 19, 2015. No. 991.

${ }^{18}$ Order of the Government of the Republic of Kazakhstan, dated August 27, 2014. No. 954.
} 
and explains the nation's financial policy. Moreover, it formulates key theses behind the outlook, principles, and the mechanism of policy implementation. At the conceptual level, public policy defines the main priorities in the financial sector development as well as the direction of and approaches to governmental regulation of its separate segments.

The financial policy of the state is shaped by and functions under the influence of interconnected objective and subjective factors ${ }^{19}$. Objective factors are related to the external environment, i.e., natural and climatic conditions, geographical, geopolitical and geoeconomic location ${ }^{20}$. Subjective factors stem from the political nature of the state and the role of public bodies. They reflect the quality and efficiency of managers, who shape the financial policy ${ }^{21}$. The cumulative effect of these various factors creates an environment for the development of the financial institutions of the Republic

Kazakh public policy in the financial sector primarily aims at the refinement of those fundamental factors that have a long-term positive effect on the functioning of financial institutions. These include the quality of governmental regulation of financial relations; quality of corporate legislation; availability of reliable and qualitative information (including financial statements) of both financial organizations and enterprises of the real sector of economy; the securities markets and free access to them; level of financial sector infrastructure and the degree of public confidence in and awareness of financial services; professional personnel training for the financial market; and refinement of the accounting systems and taxation of financial market participants.

The financial policy of the state is externalized in the strategic and program documents of social development, strategic plans of public bodies, and laws. Particular emphasis should be placed on the legalities of financial policy consolidation. Laws passed by the Parliament of the Republic of Kazakhstan, as the supreme representative authority of the state, will always have a political angle to its objectives. It is through these laws that the government implements its economic, social, and administrative policies. They, in turn, influence the implementation of the state's financial policy.

The various aspects of financial policy tend to be classified into different categories in academic studies. Some authors confine themselves to budget policy, tax policy, customs policy, and investment policy; ${ }^{22}$ others may look at tax policy, budget policy, business entities, and public borrowing ${ }^{23}$. This makes the literature on financial policy studies incomplete.

To overcome the problems posed by such classification, we consider the principle of policy consistency and differentiation. Consistency includes all elements of the financial system and is an expression of its qualitative features. At the conceptual level, this helps to clarify the vision and priorities of the Republic's financial sector development, as well as its goals and mechanism of policy implementation. However, consistency of financial policy does not exclude its differentiation. Financial policy can be distinguished by the sphere

\footnotetext{
${ }^{19}$ Gregorio (2010).

${ }^{20}$ Warnock, Cleaver (2003).

${ }^{21}$ Brealey (1999).

${ }^{22}$ Kuznetsova (2012).

${ }^{23}$ Melnikov (2005).
} 
of impact based on its classification (economic, social, regional, and external), branch of public administration, and subject of financial regulation. The classification should have both theoretical and practical significance.

State policy is often expressed in a special article of an enacted law. For example, Article 10 of the Tax Code of the Republic of Kazakhstan tax policy describes "a set of measures for the establishment of new and the abolition of effective taxes and other obligatory payments to the budget, the alteration of rates, items of taxations and items associated with the taxation, the tax base on taxes, and other obligatory payments to the budget for ensuring the financial demands of the state on the basis of observance of the balance of economic interests of the state and the taxpayers" 24 . Here, although there is a detailed description of the tax policy, the tax policy covers much more as a concept and in fact has a conceptual basis.

Financial policy is linked to the objectives of public administration. Public finance is a conscious, purposeful activity of authorized bodies and is based on the knowledge of economic laws, related to the development of managerial decisions and decision making, the execution of these laws, regulation of the socioeconomic processes, and summary of the results of this activity. The concept of management by objectives was developed in the middle of the last century (P. Drucker, D. McGregor, E. Schleh, etc.) ${ }^{25}$ and was further developed in theory and management practice ${ }^{26}$.

Public finance is aimed at the achievement of practical results in the economic, social, administrative, and political spheres of society (for example, by financing various projects and programs). It eventually extends to providing for the financial well-being of people, their quality of life, their moral and physical development, and their legal and social security. Considering the probabilistic nature of the development of the Kazakh financial system, appropriate techniques are required to formulate the objectives. Concepts such as forecasting, planning, programming, long-term priorities, etc., are an integral part of management practice. Their introduction into the financial sector of the Republic is inevitable because they are essential technical-methodological techniques.

Public finance comprises a complex, multilevel system of formal guidelines aimed at providing oversight of public bodies at any given moment; a unity of structure exists of social development requirements and political and legal forms of their fixation. This system includes a hierarchy of objectives depending on the sources of their formation, competence of public bodies, territory and time parameters.

The main objective of Kazakhstan's financial sector management is as follows: creating a sustainable and efficient financial system that satisfies the requirements of the real sector of economy for financial resources and providing quality services to individuals and legal entities by financial institutions under conditions of free competition in accordance with the "Kazakhstan 2050" strategy. Therefore, the main focus is placed on the development of Kazakhstan's financial system in accordance with its development strategy for the given period.

${ }^{24}$ Code of the Republic of Kazakhstan, dated December 10, 2008 No. 99-IV.

${ }^{25}$ Kunz, O’Donnell (1981).

${ }^{26}$ Uvarov, Uvarova (2014). 
Achieving this objective requires solving tasks different in character, content, and social significance. In the conceptual aspect, these tasks include reducing the costs of maintaining the financial system in the event of potential shocks; increasing the efficiency of the financial sector under conditions of economic integration and globalization; refining the infrastructure and creating optimal conditions for high-quality development of the financial system; expanding the reserves of growth for the financial sector, even at the expense of financial products that meet the economy's requirements; and maintaining balanced economic conditions and lowering credit risks in the economy. The use of financial instruments can help to effectively solve practical tasks, such as enhancing the competitiveness of the Kazakh economy and modernizing internal economic relations and external financial connections.

Guided by the concept of management by objectives, a budgeting system based on efficiency and performance indicators is being implemented, indicating efforts toward the modernization of the Republic's financial sector. This is being supplemented by a complex system of monitoring and evaluation of the activity of public bodies, which helps to determine the extent to which objectives have been achieved, the quality of public services provided to businesses and the population, and the efficiency of funds use. Strategic planning, financial programming, and project management are considered to be essential to change in the public administration of the Republic in the near future.

\section{Reform of the Kazakh financial system}

Reform of the Kazakh financial system includes the formation of the Republic's financial infrastructure, development of the financial sector and its separate segments within the country, creation of a competitive national financial system and its convergence with international standards and the EU regulations. The reform strictly conforms to the conceptual approaches to the modernization of the national financial system, considering the "Kazakhstan 2050" strategy, the Concept of Development of the Financial Sector of the Republic of Kazakhstan until 2030, the Kazakhstan-EU Enhanced Partnership and Cooperation Agreement (2015), and the Kazakh State program, "Path to Europe, 2009-2011". The need to make the Kazakh financial system converge with international standards and EU regulations is the harmonization of the Republic's external economic activity in terms of goods and services. In this respect, particular emphasis should be placed on those services that significantly need convergence. In practice, convergence with international regulations and European standards of the regulatory framework is necessary for enterprises and entrepreneurship; banking operations; accounting and company taxation; occupational safety; financial services; competition rules; human, animal, and plant health protection; environmental protection; consumer rights protection; customs regulations; technical regulations and standards, and elimination of discrepancies in standardization, certification, etc.

However, international rules and regulations have already been implemented in the regulatory framework of the Kazakh financial system. Key directions in the modernization of the Kazakh financial system can be determined by looking at international standards and rules 
as well as the decisions and recommendations of international financial organizations. First and foremost is monetary policy convergence with the standards of the EU. Currency relations were liberalized to shift to the principles of full national currency convertibility and domestic exchange market development, with some restrictions on the most attractive and economically viable currency operations being lifted; loan offices were created; control of "banking conglomerates" was deemed appropriate to limit risks that could affect the bank and associated members of the conglomerate; and a memorandum on cooperation and collaboration was developed so that banks could increase the transparency of their activities.

A plan of action to manage increased risks in the financial market has been designed and implemented to create an effective financial structure in Kazakhstan and enhance public confidence in the domestic financial system. To bring the Kazakh banking sector regulations in line with international standards, measures have been taken to bring the Kazakh banking system under the purview of the new capital adequacy agreement proposed by the Basel Committee on Banking Supervision-International Convergence of Capital Measurement and Capital Standards (Basel II).

A system of mandatory safeguarding of private individuals' deposits in second-tier banks has been introduced, and a securities market has been successfully established. Development institutions have been established to improve and increase the efficiency of public investment as well as to attract foreign and domestic investment in the economy.

The Concept of Development of the Financial Sector of the Republic of Kazakhstan until 2030 defines the following priorities: consolidating the banking sector and increasing capitalization; providing continuous participation of the National Bank of Kazakhstan in the money market, and stimulating the development of the interbank market; regulating the financial market; securing and efficiently managing the capital of financial organizations; developing and consolidating the stock market within the framework of the "National IPO"; providing the public with better access to financial services; increasing the role of qualified investors in investment operations and risk taking with higher requirements for management and capital adequacy; limiting direct state participation in the financial system through institutions of development not in competition with private financial institutions; increasing the autonomy and independence of the institutional structure of the National Bank in terms of decision-making with regard to the control and supervision of the financial market and financial organizations; and maintaining a financial system with primarily domestic capital.

A prerequisite for making the Kazakh financial system converge with international standards and EU regulations is the elimination of contradictions between the domestic and the European financial sector regulatory framework. In addition, clear safeguards must be provided with respect to unlawful actions by public agencies and their executives against economic entities (both resident and non-resident) engaging in entrepreneurial activity in Kazakhstan. This condition is fundamental to the establishment of partnership with EU and Western countries. The fact is that international business practice currently recognizes the principle of "legal certainty". It implies maximum transparency of national legislation with regard to the financial and entrepreneurial activity of legal entities, free access to 
this legislation, instructions on legal restrictions on legal entities and sanctions for their violation.

Determining the terms and conditions of the legal framework that affect the activity of Kazakh companies in EU countries and vice versa poses a problem. Inconsistency between the Kazakh regulatory framework for financial and economic issues and, for example, European standards creates an opportunity for disputes. This may happen with regard to the Kazakh companies in the European market, where they can be held responsible for the violation of various rules and regulations of the EU (environmental, tax, competition, etc.). Such violations are regarded as criminal acts. However, no penal code exists in the EU; only various directives and public sanctions (fines, suspension of operations, etc.) exist for violating them. All of this requires the managers of companies operating in the European market and in other countries to first study the rules (regulations, directives, etc.) in the business sector effective there.

This also involves providing discrimination-free access to competent courts and public authorities for private individuals and legal entities of the other party so that they can protect their individual rights in the financial and economic sphere, including proprietary rights.

The "Kazakhstan 2050" strategy aims at the next stage in the modernization of the national financial system in order for it to be able to ensure the Republic's economic development and synchronize it with the dynamic international financial environment. This implies enhancing the competitiveness of the Kazakh financial system in all its core segments. Taxation rules require particular improvement because clear taxation rules and regulations are one of the key factors leading to a better investment climate and attracting domestic and foreign investors. Studies on the problems associated with taxation are particularly useful, specifically those conducted by Igor Kotlan and Zuzana Machova ${ }^{27}$ and by Matej Kacaljak on maintaining currency consistency in the Eurozone and on the efficiency of economic and legal methods of enforcing budgetary discipline on member states ${ }^{28}$. Franjo Stiblar's examination of the causes of the world crisis, and the mechanism to overcome it in the Eurozone also offers useful insights ${ }^{29}$. Particularly interesting is the study by Tanja Borzl on the implementation of standards and regulations in the context of new control regimes in Europe ${ }^{30}$.

The overhauling of the customs system should focus on simplifying customs procedures to eliminate discrepancies that can hinder the development of international trade and exchange and to stimulate international cooperation. This requires the reduction of administrative barriers; application of modern customs administration methods; maximum use of information technology; and introduction of international customs standards to ensure predictability, consistency, and transparency of customs rules and procedures.

\footnotetext{
27 Kotlan, Machova (2012).

28 Kacaljak (2011).

${ }^{29}$ Stiblar (2011).

${ }^{30}$ Borzl (2011).
} 
The convergence of the Kazakh financial system with international standards and EU regulations involves the development of a mechanism for their transformation into the national regulatory framework and the incorporation of universally recognized standards and regulations into the Republic's financial system. The need of the hour is to devise a systematic record of existing regulations and rules on financial activity in Kazakhstan, fill the void in financial relations regulation, simplify registration and licensing procedures for entrepreneurial activities of individuals and legal entities, and impose restrictions on unlawful interference by public authorities in the activities of commercial and noncommercial financial institutions. The problem of financial activity forecasting requires special attention. It should be based on the constant monitoring of trends in the development of the global financial sector and the analysis of the practices of various financial institutions. This will enable to ascertain the actual situation in financial sector regulation on the one hand. On the other hand, it will highlight the void in financial legislation and the penal system for economic entities for various violations of financial regulations and rules.

When Kazakstan enters the WTO and switches to international standards of financial regulation, its financial organizations will have to operate under conditions of free competition and confront challenges inevitably posed by the penetration of financial services provided by international and European rival financial organizations in the Kazakh market without a commercial presence (through their branches).

\section{Conclusion}

The Kazakhstan-EU Enhanced Partnership and Cooperation Agreement (2015) provides a basis for the development of bilateral relations in various areas of mutual interests. In this case, Kazakhstan plays an important role in the implementation of the Strategy of a New Partnership between the EU and Central Asia ${ }^{31}$. According to President Nazarbayev, "Kazakhstan is ready to serve as the gateway to Central Asia for the EU"32. The prospect of a Kazakhstan-EU partnership suggests the specification of a long-term financial policy, strategic and program documents, and national legislation.

The parties have agreed on the need to bridge gaps in many areas, including in the financial sector. This, in turn, dictates the need to begin working on the convergence of the Kazakh financial system with international standards and EU regulations.

The modernization of the Kazakh financial system includes a complex of urgent practical measures aimed at a systematic arrangement of the existing rules and regulations on financial activity in the Republic, eliminating discrepancies between the national regulatory framework and international standards and the EU regulations; and maintaining the stability and competitiveness of the financial system.

\footnotetext{
31 The Regional Strategy Paper for Assistance to Central Asia (2007-2013) (2007).

${ }^{32}$ Nazarbayev (2010).
} 
The establishment of clear security guarantees for foreign investors and measures against unlawful actions taken by public agencies and their executives against economic entities is a prerequisite for the Kazakh financial system's convergence with Western countries. The regulatory framework of the Republic's financial sector must be available to foreign investors, and its transparency is the prerequisite for the international principle of "legal certainty".

\section{References}

Abishev, A. A., Sidorovich, A. V. (2009). National economy: Textbook. Almaty: Ekonomika.

Borzl, T. (2011). Move closer! New modes of governance and accession to the European Union. DANUBE: Law and Economics Review, 2, 1-22.

Brealey, R. (1999). The Asian Crisis: Lessons for Crisis Management and Prevention. International Finance, 2(2), 249-272.

Code of the Republic of Kazakhstan, dated December 10, 2008. No.99-IV. On taxes and other obligatory payments to the budget (Tax Code). Retrieved April 4, 2016, from http://adilet.zan.kz/rus/docs/K080000099_.

Decree of the President of the Republic of Kazakhstan, dated August 29, 2008. No. 653. On the State program "Path to Europe" for 2009-2011. Retrieved April 4, 2016, from http://adilet.zan.kz/rus/docs/U080000653_.

Decree of the President of the Republic of Kazakhstan, dated February 1, 2010. No. 922. On the strategic plan for the development of the Republic of Kazakhstan until 2020. Retrieved April 4, 2016, from http://adilet.zan.kz/rus/docs/U100000922_.

Decree of the President of the Republic of Kazakhstan, dated January 19, 2015. No. 991. On the initialling of the draft Agreement on enhanced partnership and cooperation between Kazakhstan and the European Union. Retrieved April 4, 2016, from http://adilet.zan.kz/rus/ docs/U1500000991.

European Commission. (2006). Commissioner Ferrero-Waldner to visit Kazakhstan 19/20 October 2006 (2006). Retrieved April 4, 2016, from http://europa.eu/rapid/press-release_IP06-1420_en.htm.

Georg-Eckert-Institut - Leibniz-Institut für internationale Schulbuchforschung (2016). EU and Central Asia: new partnership strategy. Adopted at the European Union Summit. June 2007. Retrieved April 4, 2016, from http://www.amudarya.net/fileadmin/_amudarya/bs/euca.pdf.

Gregorio, J. (2010). Monetary Policy and Financial Stability: An Emerging Markets Perspective. International Finance, 13(1), 141-156.

Intykbayeva, S. Zh. (2007). Public finance: Textbook. Almaty: Evero.

Kacaljak, M. (2011). The debt crisis and the means of enforcing the budgetary discipline of EU Member States. DANUBE: Law and Economics Review, 4, 63-79.

Kotlan, I., Machova, Z. (2012). World tax index: methodology and data. DANUBE: Law and Economics Review, 2, 19-33. 
Kunz, G., O’Donnell, C. (1981). Management: a situational and system analysis management functions: In 2 volumes. Transl. from English. Moscow: Progress.

Kuznetsova, Y. (2012). Finance. Money circulation. Credit: Textbook. Moscow: UNITYDANA.

Law of the Republic of Kazakhstan, dated December 6, 2001, No. 264-II "On the membership of the Republic of Kazakhstan in the International Monetary Fund, International Bank for Reconstruction and Development, International Finance Corporation, International Development Association, Multilateral Investment Guarantee Agency, International Center for Settlement of Investment Disputes, European Bank of Reconstruction and Development, Asian Development Bank, Islamic Development Bank". Bulletin of the Parliament of the Republic of Kazakhstan. 2001. No. 23. P. 313.

Law of the Republic of Kazakhstan, dated May 30, 2005. No. 54 "On international treaties of the Republic of Kazakhstan". Bulletin of the Parliament of the Republic of Kazakhstan. 2005. No. 10. P. 35.

Melnikov, V. D. (2005). Fundamentals of finance: Textbook. Almaty: LEM Publishing LLP.

Melnikov, V. D. (2013). Finance. Almaty: Ekonomika.

Nazarbayev, N. (2010). Kazakhstan is ready to become the EU "gateway" to Central Asia. Diapazon, April 11, 2010. Retrieved April 4, 2016, from http://www.diapazon.kz/kazakhstan/kazpolitics/26735-kazakhstan-gotov-stat-dlja-es-vorotami-v.html.

Nazarbayev, N. (2012). “Strategy Kazakhstan-2050” - New political course of the established state. Retrieved April 4, 2016, from http://adilet.zan.kz/rus/docs/K1400002014 (as of 17.01.2014).

Order of the Government of the Republic of Kazakhstan, dated August 27, 2014. No. 954. On the approval of the Concept of development of financial sector of the Republic of Kazakhstan until 2030. Retrieved April 4, 2016, from http://adilet.zan.kz/rus/docs/P1400000954. Regulatory Statute of the Constitutional Council of the Republic of Kazakhstan, dated November 5, 2009. No. 6. "On the official interpretation of the regulations of the article 4 of the Constitution of the Republic of Kazakhstan relating to the procedures of enforcement of decisions made by international organizations and their agencies". Collection of Resolutions of the Constitutional Council of the Republic of Kazakhstan. Astana, 2010. P. 499.

Stiblar, F. (2011). The Global Crisis and the Western Balkans. DANUBE: Law and Economics Review, 3, 23-46.

The Constitution of the Republic of Kazakhstan, adopted at the Republican Referendum on August 30, 1995. Bulletin of the Parliament of the Republic of Kazakhstan. 1996. No. 4. P. 217.

The Regional Strategy Paper for Assistance to Central Asia (2007-2013). In: European Community. 2007.61 p. Retrieved from http://www.eeas.europa.eu/central_asia/rsp/07_13 _en.pdf.

Utibayev, B. S., Zhunusova, R. M., Satkaliyeva, V. A. (2006). State budget: Textbook. Almaty: Ekonomika. 
Uvarov, V., Uvarova, N. (2014). Theory of public administration: Textbook. Almaty: Kunaev University.

Warnock, F. E., Cleaver, C. (2003). Financial Centres and the Geography of Capital Flows. International Finance, 6(1), 27-59. 